\title{
Hubungan antara Stres Akademik dengan Kecenderungan Gejala Somatisasi pada Mahasiswa Program Studi Kedokteran Tingkat Akhir Fakultas Kedokteran Universitas Andalas Angkatan 2015
}

\author{
Viton Surya Irlaks ${ }^{1}$, Arina Widya Murni ${ }^{2}$, Rini Gusya Liza ${ }^{3}$
}

\begin{abstract}
Abstrak
Stres akademik merupakan suatu keadaan emosional yang paling umum dialami oleh mahasiswa selama masa studi. Stres yang tidak dikontrol dengan baik dapat mempengaruhi terjadinya gejala somatisasi. Tujuan: Menentukan hubungan antara stres akademik dengan kecenderungan gejala somatisasi pada mahasiswa program studi kedokteran tingkat akhir Fakultas Kedokteran Universitas Andalas angkatan 2015. Metode: Penelitian ini adalah analitik dengan desain cross sectional. Responden penelitian adalah 100 orang mahasiswa program studi kedokteran tingkat akhir Fakultas Kedokteran Universitas Andalas Angkatan 2015. Pengambilan sampel dilakukan dengan teknik random sampling berdasarkan kriteria inklusi dan ekslusi. Instrumen penelitian ini menggunakan kuesioner Medical Student Stress Questionnaire (MSSQ) dan The Somatic Symptom Scale - 8 (SSS-8). Data dianalisis menggunakan uji bivariat Fisher's exact. Hasil: Penelitian menunjukkan 43 orang (43\%) adalah laki - laki dan 57 orang (57\%) adalah perempuan. Usia terbanyak adalah 21 tahun (74\%) dan paling sedikit 20 tahun (9\%). Tingkat stres akademik 56 orang sedang (56\%) dan 4 orang sangat berat (4\%). Tingkat kecenderungan gejala somatisasi 26 orang sedang $(26 \%)$ dan 11 orang sangat ringan (11\%). Sebanyak 24 orang yang mengalami stres akademik memiliki kecenderungan gejala somatisasi sedang $(27,9 \%)$. Analisis bivariat menunjukkan nilai $p=0,000(p<0,05)$. Simpulan: Terdapat hubungan yang bermakna antara stres akademik dengan kecenderungan gejala somatisasi pada mahasiswa program studi kedokteran tingkat akhir Fakultas Kedokteran Universitas Andalas angkatan 2015.
\end{abstract}

Kata kunci: stres akademik, gejala somatisasi, mahasiswa tingkat akhir

\section{Abstract}

Academic stress is the most common emotional condition experienced by students during the study period. Stress which is not controlled well can affect the occurrence of symptoms of somatization. Objectives: To determined the relationship between academic stress and somatic symptom tendency in final year student of medical study program of Medical Faculty of Universitas Andalas batch 2015. Methods: This was analytic with cross-sectional design. The research respondents were 100 medical students of final year. Sampling was done by random sampling technique based on inclusion and exclusion criteria. The instrument of this study used the Medical Student Stress Questionnaire (MSSQ) questionnaire and The Somatic Symptom Scale - 8 (SSS-8). Data were analyzed by using Fisher's exact bivariate test. Results: 43 people (43\%) were male and 57 people (57\%) were women. The highest age was 21 years (74\%) and the least age was 20 years (9\%). Moderate academic stress levels were 56 people (56\%) and 4 people were very heavy (4\%). The moderate level of tendency of somatization symptoms was 26 people (26\%) and 11 people were very mild (11\%). As many as 24 people who experience academic stress have a tendency to moderate somatization symptoms (27.9\%). Bivariate analysis was $p=0,000(p<0.05)$. Conclusion: There was a significant relationship between academic stress and somatic symptom tendency in final year student of medical study program of Medical Faculty of Andalas University batch 2015. 
Affiliasi penulis: ${ }^{1}$ Program Studi Kedokteran, Fakultas Kedokteran, Universitas Andalas, Padang, Indonesia. ${ }^{2}$ Bagian IImu Penyakit Dalam, Fakultas Kedokteran, Universitas Andalas, Padang, Inodonesia. ${ }^{3}$ Bagian IImu Kedokteran Jiwa, Fakultas Kedokteran, Universitas Andalas, Padang, Indonesia.

Korespondensi: Viton Surya Irlaks, Email : vithon86@gmail.com Telp: 081277593770

\section{PENDAHULUAN}

Stres merupakan istilah yang digunakan untuk menggambarkan respon fisik, emosional, kognitif, dan perilaku terhadap peristiwa yang dinilai sebagai ancaman atau tantangan. ${ }^{1}$ Stres juga merupakan gangguan emosional atau perubahan lingkungan disebabkan oleh stresor. ${ }^{2}$ Stres tersebut dapat berasal dari individu itu sendiri, lingkungan keluarga, lingkungan tempat tinggal dan dapat pula berasal dari tempat - tempat dimana individu banyak menghabiskan waktunya seperti kantor dan tempat pendidikan. ${ }^{3}$

Stres akademik merupakan suatu keadaan emosional atau mental paling umum yang dialami oleh mahasiswa selama masa studi mereka. ${ }^{4}$ Stres akademik juga dapat diartikan sebagai suatu keadaan individu yang mengalami tekanan hasil persepsi dan penilaian tentang stresor akademik yang berhubungan dengan ilmu pengetahuan dan pendidikan di perguruan tinggi. $^{5}$ Stres akademik juga dapat didefinisikan sebagai perasaan tertekan yang disebabkan oleh keterbatasan waktu dan ketidakmampuan dalam menguasai suatu ilmu pengetahuan. $^{6}$

Beberapa hal yang menyebabkan stres akademik adalah beban ujian, sistem pendidikan yang berbeda, dan memikirkan rencana masa depan setelah kelulusan. ${ }^{4}$ Selain itu, mahasiswa perguruan tinggi yang mengalami stres tinggi bisa dikarenakan berbagai alasan seperti kurangnya persiapan, gaya belajar dan kurangnya informasi yang dibutuhkan. ${ }^{7}$

Penelitian yang dilakukan di Universitas Lampung terhadap 100 mahasiswa angkatan akhir, terdapat 45 responden (45\%) mengalami stres ringan, 47 responden $(47 \%)$ mengalami stres sedang dan 8 responden $(8 \%)$ mengalami stres berat. $^{8}$
Tingkat stres pada mahasiswa kedokteran cenderung berkisar dari $25 \%$ sampai $75 \%{ }^{9}$ Berdasarkan hasil penelitian yang dilakukan pada 100 mahasiswa Fakultas Kedokteran Universitas Sumatera Utara semester ganjil tahun akademik 2012/2013 yang terdiri dari semester ganjil 1, 3, 5 dan 7 didapatkan bahwa gambaran tingkat stres pada mahasiswa menunjukan sebanyak 35 orang (35\%) mengalami stres tingkat rendah, 61 orang $(61 \%)$ mengalami stres tingkat sedang dan 4 orang (4\%) mengalami stres tingkat tinggi. ${ }^{10}$

Penelitian yang dilakukan pada 375 mahasiswa kedokteran dan mahasiswa kedokteran gigi di Universitas Kathmandu didapatkan bahwa $41 \%$ mahasiswa kedokteran mengalami stres dan $34 \%$ mahasiswa kedokteran gigi mengalami stres. ${ }^{11}$

Somatisasi merupakan gangguan yang tidak dapat diterangkan oleh medis, serta berhubungan dengan masalah stres. ${ }^{12,13}$ Gangguan somatisasi juga merupakan salah satu bentuk gangguan somatoform, yang sumber gangguannya adalah kecemasan yang dimanifestasikan dalam keluhan fisik, sehingga orang lain tidak akan mengerti jika individu tidak mengeluh. ${ }^{14,15}$ Gangguan somatisasi ini juga dapat menimbulkan munculnya rasa cemas dan depresi yang berlebihan. ${ }^{15}$

Berdasarkan hasil wawancara pada bulan Juni Juli 2012 yang dilakukan pada sepuluh orang mahasiswi program studi Farmasi Fakultas IImu Kesehatan Universitas Muhammadiyah Palangkaraya, didapatkan bahwa mereka sering mengeluh mengalami sakit kepala, dispepsia, badan sering pegal-pegal, otot terasa tegang dan keluhan lain tanpa sebab yang jelas. Delapan orang dari mereka tidak mengetahui penyebab keluhan tersebut dan menurut mereka hal itu sudah biasa mereka alami, sedangkan dua orang lainnya mengatakan bahwa mereka mengalami keluhan tersebut saat kondisi tubuh mereka kurang sehat atau lemah. Beberapa dari mereka mengaku bahwa keluhan tersebut mengganggu aktivitas mereka sehari-hari. ${ }^{16}$

Berdasarkan penelitian yang dilakukan pada bulan Desember 2012 dengan jumlah sampel sebanyak 100 
orang mahasiswi yang terdiri dari semester 5 dan semester 7 di Fakultas Farmasi Universitas Muhammadiyah Palangkaraya, didapatkan bahwa 3\% mahasiswi mengalami kecenderungan gejala somatisasi ringan, $33 \%$ mahasiswi mengalami kecenderungan gejala somatisasi sedang, dan $64 \%$ mahasiswi mengalami kecenderungan gejala somatisasi berat. Berdasarkan hasil penelitian tersebut, dapat disimpulkan bahwa mahasiswi Fakultas Farmasi semester 5 dan semester 7 Universitas Muhammadiyah Palangkaraya memiliki kecenderungan gejala somatisasi yang relatif tinggi. ${ }^{16}$

Berdasarkan uraian latar belakang di atas, diketahui bahwa stres merupakan kondisi yang umumnya dialami oleh mahasiswa kedokteran dan dengan adanya beban akademik yang banyak dan berat dapat menimbulkan tekanan pada mahasiswa kedokteran. Oleh karena itu, perlu diteliti hubungan stres akademik dengan kecenderungan gejala somatisasi pada mahasiswa kedokteran tingkat akhir.

\section{METODE}

Jenis penelitian ini adalah analitik korelatif dengan rancangan cross-sectional. Variabel independen adalah stres akademik dan variabel dependennya adalah gejala somatisasi. Penelitian dilakukan dari bulan Oktober 2018 sampai Januari 2019 di Fakultas Kedokteran Universitas Andalas, Jati, Kota Padang, Sumatera Barat.

Populasi penelitian ini adalah semua mahasiswa program studi kedokteran tingkat akhir Fakultas Kedokteran Universitas Andalas angkatan 2015.

Sampel penelitian yang dipilih adalah mahasiswa program studi kedokteran tingkat akhir Fakultas Kedokteran Universitas Andalas angkatan 2015 yang memenuhi kriteria inklusi dan eksklusi. Kriteria inklusi sampel adalah mahasiswa yang bersedia menjadi responden. Kriteria eksklusi sampel adalah mahasiswa yang didiagnosis memiliki gangguan medis berat oleh dokter, mahasiswa yang didiagnosis memiliki gangguan psikiatri oleh dokter dan mahasiswi yang sedang menstruasi.

Pengumpulan data didapatkan dengan menggunakan kuesioner yang diisi oleh responden. Terdapat dua kuesioner yang digunakan dalam penelitian ini, yaitu kuesioner MSSQ (Medical Student
Stressor Questionnaire) dan SSS-8 (The Somatic Simptom Scale-8). Kuesioner MSSQ merupakan kuesioner yang dirancang untuk mengetahui tingkatan stres pada mahasiswa kedokteran. ${ }^{17}$ Kuesioner SSS-8 merupakan kuesioner yang digunakan untuk menilai berat ringannya gejala somatik yang dirasakan seseorang. ${ }^{18}$

Data dianalisis secara statistik berdasarkan variabel yang dinilai menggunakan sistem komputerisasi yaitu analisis univariat dan bivariat. Analisis univariat dilakukan untuk melihat distribusi frekuensi dari masing-masing variabel independen dan variabel dependen. Analisis bivariat dilakukan untuk menganalisis hubungan antara variabel independen dan variabel dependen. Hubungan dua variabel tersebut dianalisis dengan menggunakan uji ChiSquare dan dikatakan bermakna bila $p<0.05$.

Penelitian dilaksanakan setelah mendapatkan persetujuan etik dari Komite Etika Penelitian Fakultas Kedokteran nomor: 705/KEP/FK/2019.

\section{HASIL}

Penelitian telah dilakukan di Fakultas Kedokteran Universitas Andalas pada tanggal 31 November sampai dengan 1 Desember 2018. Berdasarkan 120 kuesioner yang telah diberikan kepada mahasiswa program studi kedokteran tingkat akhir angkatan 2015, didapatkan 100 responden yang memenuhi kriteria inklusi dan tidak memiliki kriteria eksklusi serta telah lulus dari pertanyaan penyaring. Jumlah sampel pada penelitian ini telah mencukupi jumlah sampel minimal penelitian. Data hasil penelitian dikumpulkan dan untuk dianalisis. Analisis data yang dilakukan meliputi analisis univariat dan analisis bivariat.

\section{Analisis Univariat}

Tabel 1. Distribusi frekuensi karakteristik responden berdasarkan usia dan jenis kelamin

\begin{tabular}{clcc}
\hline No & Karakteristik & $\mathrm{n}$ & $\%$ \\
\hline 1 & Usia & 9 & 9 \\
& 20 tahun & 74 & 74 \\
& 21 tahun & 17 & 17 \\
& $>21$ tahun & & \\
& Jenis Kelamin & 43 & 43 \\
& Laki - laki & 57 & 57
\end{tabular}


Hasil analisis pada Tabel 1 menunjukkan bahwa paling banyak responden berusia 21 tahun yaitu 74 orang $(74 \%)$, diikuti oleh $>21$ tahun yaitu 17 orang $(17 \%)$ dan 20 tahun yaitu 9 orang (9\%). Usia responden yang paling muda adalah 20 tahun dan yang paling tua adalah $>21$ tahun. Sebagian besar responden berjenis kelamin perempuan, yaitu sebanyak 57 orang (57\%), sedangkan responden yang berjenis kelamin laki - laki, yaitu sebanyak 43 orang (43\%).

Tabel 2. Distribusi frekuensi karakteristik tingkat stres akademik responden berdasarkan jenis kelamin

\begin{tabular}{|c|c|c|c|c|c|}
\hline \multirow{4}{*}{\multicolumn{2}{|c|}{ Variabel }} & \multicolumn{4}{|c|}{ Tingkat Stres Akademik } \\
\hline & & \multirow{2}{*}{\multicolumn{2}{|c|}{$\begin{array}{c}\text { Stres } \\
\text { Akademik }\end{array}$}} & \multirow{2}{*}{\multicolumn{2}{|c|}{$\begin{array}{l}\text { Tidak Stres } \\
\text { Akademik }\end{array}$}} \\
\hline & & & & & \\
\hline & & $f$ & $\%$ & $f$ & $\%$ \\
\hline Jenis & Pria & 35 & 40,7 & 8 & 57,1 \\
\hline \multicolumn{6}{|c|}{ Kelamin } \\
\hline & Wanita & 51 & 59,3 & 6 & 42,9 \\
\hline \multicolumn{2}{|c|}{ Total } & 86 & 100 & 14 & 100 \\
\hline
\end{tabular}

Berdasarkan analisis hasil Tabel 2 di atas, didapatkan bahwa responden yang mengalami stres paling banyak adalah wanita yaitu 51 orang (59,3\%), sedangkan responden yang tidak mengalami stres paling banyak adalah pria yaitu 35 orang $(40,7 \%)$.

Tabel 3. Distribusi frekuensi tingkat stres akademik responden

\begin{tabular}{ccc}
\hline $\begin{array}{c}\text { Kategori Stres } \\
\text { Akademik }\end{array}$ & Frekuensi & Persentase (\%) \\
\hline Ringan & 14 & 14 \\
Sedang & 56 & 56 \\
Berat & 26 & 26 \\
Sangat Berat & 4 & 4 \\
\hline
\end{tabular}

Tabel 3 menunjukan bahwa tingkat stres akademik yang paling banyak dialami responden adalah stres akademik sedang yaitu 56 orang (56\%), sedangkan tingkat stres akademik sangat berat hanya dialami oleh 4 orang (4\%).
Tabel 4. Gambaran stres akademik berdasarkan jawaban responden

\begin{tabular}{|c|c|c|c|}
\hline No. & Item & Rerata & SD \\
\hline 1 & Ujian & 1,97 & $\pm 0,745$ \\
\hline 4 & $\begin{array}{l}\text { Sistem penilaian } \\
\text { pada ujian }\end{array}$ & 1,62 & $\pm 0,930$ \\
\hline 7 & $\begin{array}{lr}\text { Merasa } & \text { harus } \\
\text { melakukan } & \text { sesuatu } \\
\text { dengan } & \text { baik } \\
\text { (keinginan } & \text { dari diri } \\
\text { sendiri) } & \end{array}$ & 1,83 & $\pm 0,911$ \\
\hline 10 & $\begin{array}{l}\text { Beban kuliah yang } \\
\text { banyak }\end{array}$ & 1,88 & $\pm 0,808$ \\
\hline 12 & $\begin{array}{l}\text { Ketertinggalan } \\
\text { dalam belajar }\end{array}$ & 1,81 & $\pm 0,929$ \\
\hline 17 & $\begin{array}{l}\text { Praktik skill lab yang } \\
\text { tidak mencukupi }\end{array}$ & 1,34 & $\pm 0,913$ \\
\hline 19 & $\begin{array}{l}\text { Konteks belajar } \\
\text { yang penuh } \\
\text { kompetisi }\end{array}$ & 1,70 & $\pm 0,969$ \\
\hline 23 & $\begin{array}{l}\text { Kesulitan dalam } \\
\text { memahami isi } \\
\text { pelajaran }\end{array}$ & 1,57 & $\pm 0,868$ \\
\hline 25 & $\begin{array}{l}\text { Mendapatkan nilai } \\
\text { yang jelek }\end{array}$ & 2,15 & $\pm 1,009$ \\
\hline 27 & $\begin{array}{l}\text { Kekurangan waktu } \\
\text { untuk mengulangi } \\
\text { pelajaran }\end{array}$ & 1,82 & $\pm 1,048$ \\
\hline 30 & $\begin{array}{l}\text { Tidak bisa } \\
\text { menjawab } \\
\text { pertanyaan dosen }\end{array}$ & 1,56 & $\pm 0,903$ \\
\hline 33 & $\begin{array}{l}\text { Luasnya cakupan } \\
\text { yang harus dipelajari }\end{array}$ & 1,77 & $\pm 0,941$ \\
\hline 36 & $\begin{array}{l}\text { Proses penilaian } \\
\text { yang tidak adil }\end{array}$ & 1,80 & $\pm 1,025$ \\
\hline
\end{tabular}

Berdasarkan Tabel 4 diperoleh data bahwa skor rerata tertinggi terdapat pada pernyataan nomor 25 $(2,15)$, yaitu mendapatkan nilai yang jelek. Hal ini menunjukkan bahwa pernyataan tersebut paling menyebabkan stres akademik. Sementara itu, pernyataan yang hanya menyebabkan sedikit stres akademik merupakan pernyataan nomor $17(1,34)$ yaitu praktik skill lab yang tidak cukup. 
Tabel 5. Distribusi tingkat kecenderungan gejala somatisasi responden

\begin{tabular}{ccc}
\hline $\begin{array}{c}\text { Kategori } \\
\text { Kecenderungan } \\
\text { Gejala } \\
\text { Somatisasi }\end{array}$ & Frekuensi & Persentase (\%) \\
\hline Sangat Ringan & 11 & 11 \\
Ringan & 24 & 24 \\
Sedang & 26 & 26 \\
Berat & 23 & 23 \\
Sangat Berat & 16 & 16 \\
\hline
\end{tabular}

Tabel 5 menunjukan tingkat kecenderungan gejala somatisasi yang paling banyak dialami responden adalah kecenderungan gejala somatisasi sedang yaitu 26 orang (26\%), sedangkan tingkat kecenderungan gejala somatisasi sangat ringan hanya dialami oleh 11 orang (11\%).

Tabel 6. Gambaran tingkat kecenderungan gejala somatisasi berdasarkan jawaban responden

\begin{tabular}{clcc}
\hline No. & \multicolumn{1}{c}{ Masalah Medis } & Rerata & SD \\
\hline 1 & Gangguan pencernaan & 1,14 & $\pm 0,964$ \\
2 & Nyeri punggung & 0,86 & $\pm 1,025$ \\
3 & $\begin{array}{l}\text { Nyeri di lengan, kaki, atau } \\
\text { persendian }\end{array}$ & 0,96 & $\pm 1,136$ \\
4 & Sakit kepala & 1,59 & $\pm 1,074$ \\
5 & $\begin{array}{l}\text { Nyeri dada atau nafas } \\
\text { pendek }\end{array}$ & 0,75 & $\pm 0,978$ \\
6 & $\begin{array}{l}\text { Pusing } \\
7\end{array}$ & 1,21 & $\pm 0,988$ \\
& $\begin{array}{l}\text { Merasa lelah atau sedikit } \\
8\end{array}$ & 1,99 & $\pm 1,068$ \\
& Gangguan tidur & 1,58 & $\pm 1,365$ \\
\hline
\end{tabular}

Berdasarkan Tabel 6 diperoleh data bahwa skor rata-rata tertinggi terdapat pada pernyataan nomor 7 $(1,99)$, yaitu merasa lelah atau sedikit energi. Hal ini menunjukkan bahwa pernyataan tersebut cukup sering dialami oleh responden. Sementara itu, pernyataan gejala somatisasi yang jarang dialami oleh responden merupakan pernyataan nomor $5(0,75)$ yaitu nyeri dada atau nafas pendek.
Tabel 7. Hubungan stres akademik dengan kecenderungan

\begin{tabular}{cccccc}
\hline Stres Akademik & \multicolumn{3}{c}{ Somatisasi } \\
& $\begin{array}{c}\text { Sangat } \\
\text { Ringan - } \\
\text { Ringan }\end{array}$ & $\begin{array}{l}\text { Sedang- } \\
\text { Berat- } \\
\text { Sangat } \\
\text { Berat }\end{array}$ & Total & p \\
\hline Stres & Count & 24 & 62 & 86 & \\
Tidak & Count & 11 & 3 & 100 & 0,000 \\
Stres & & 27,9 & 72,1 & 14 & \\
& $\%$ & 78,6 & 21,4 & 100 & \\
\hline Fisher's Exact Test & & & & &
\end{tabular}

Pada tabel uji silang terdapat lima sel yang memiliki frekuensi harapan (expected count) kurang dari 5. Oleh karena itu, digunakan uji alternatif ChiSquare, yaitu Fisher's Exact Test. Hasil uji statistik menggunakan Fisher's Exact Test diperoleh nilai $\mathrm{p}=$ $0,000(p<0,05)$. Berdasarkan hasil tersebut dapat disimpulkan secara statistik bahwa terdapat hubungan yang signifikan antara stres akademik dengan kecenderungan gejala somatisasi pada mahasiswa program studi kedokteran tingkat akhir Fakultas Kedokteran Universitas Andalas angkata 2015.

\section{PEMBAHASAN}

Berdasarkan penelitian yang telah dilakukan pada mahasiswa program studi kedokteran tingkat akhir Fakultas Kedokteran Universitas Andalas angkatan 2015 didapatkan bahwa sebagian besar dari mahasiswa angkatan 2015 berumur 21 tahun. Hasil penelitian ini sama dengan penelitian yang dilakukan oleh Augesti et al (2015) yaitu mahasiswa kedokteran tingkat akhirnya berusia 21 tahun dan Chandratika dan Purnawati (2014) yaitu rerata mahasiswa kedokteran tingkat akhir juga berusia 21 tahun. ${ }^{8,19}$ Semakin tua seseorang maka orang tersebut semakin rentan mengalami stres, terutama seseorang akan rentan mengalami stres pada usia 21 - 40 tahun. ${ }^{20}$

Berdasarkan hasil penelitian yang telah dilakukan, didapatkan bahwa $72,1 \%$ mahasiswa yang mengalami stres akademik berusia 21 tahun. Hasil penelitian ini juga tidak jauh berbeda dari penelitian yang dilakukan oleh Sharma et al (2011) yaitu 67,6\% 
mahasiswa yang mengalami stres akademik juga berusia 21 tahun. $^{21}$

Berdasarkan penelitian yang telah dilakukan, didapatkan bahwa jenis kelamin yang menjadi mayoritas responden pada penelitian ini adalah perempuan yaitu 57\%. Hasil penelitian ini tidak jauh berbeda dengan penelitian yang dilakukan oleh Augesti et al (2015) yaitu jenis kelamin responden yang paling banyak adalah perempuan $76,4 \%$ dan penelitian yang dilakukan oleh Pathmanathan dan Husada (2013) juga memiliki jenis kelamin responden yang paling banyak adalah perempuan $51 \%{ }^{8,10}$ Pada populasi penelitian, responden yang berjenis kelamin perempuan lebih banyak dari pada responden yang berjenis kelamin laki-laki.

Berdasarkan hasil penelitian, didapatkan bahwa $59,3 \%$ mahasiswa yang mengalami stres akademik berjenis kelamin perempuan. Hasil penelitian ini tidak jauh berbeda dengan penelitian yang dilakukan oleh Sutjianto et al (2015) yaitu responden yang paling banyak mengalami stres adalah perempuan 51,7\% dan penelitian yang dilakukan oleh Suwartika et al (2014) juga mendapatkan bahwa responden yang paling banyak mengalami stres adalah perempuan $58 \%$. $^{3,5}$

Perempuan lebih rentan mengalami stres dari pada laki - laki. Secara psikologis, perempuan lebih sensitif dan emosional dari pada laki - laki, sehingga memudahkan perempuan untuk mengalami stres. ${ }^{22}$

Berdasarkan hasil penelitian yang telah dilakukan pada mahasiswa program studi kedokteran tingkat akhir Fakultas Kedokteran Universitas Andalas angkatan 2015, didapatkan bahwa tingkat stres akademik responden sebagian besar berada pada kategori stres akademik sedang, yaitu sebesar $56 \%$. Persentase stres akademik berat responden sebesar $26 \%$, sedangkan stres akademik sangat berat sebesar 4\%. Peneliti menyimpulkan bahwa sebagian besar derajat stres akademik mahasiswa program studi kedokteran tingkat akhir Fakultas Kedokteran Universitas Andalas angkatan 2015 berada pada kisaran kategori sedang-berat.

Hasil penelitian ini tidak jauh berbeda dengan penelitian yang dilakukan oleh Umesh et al (2014) yaitu tingkat stres akademik responden sebagian besar juga berada pada kategori stres akademik sedang, yaitu sebesar $63 \%$. $^{23}$

Nilai yang jelek merupakan salah satu stresor akademik. Berdasarkan hasil penelitian yang telah dilakukan, didapatkan bahwa rerata tertinggi stresor akademik (mendapatkan nilai yang jelek), yaitu sebesar 2,15 (sedang-berat). Hasil penelitian ini sejalan dengan penelitian yang dilakukan oleh Othman et al (2013) terhadap stresor akademik yang sama, didapatkan rerata tertingginya sebesar 2,96 (sedangberat). ${ }^{24}$

Berdasarkan hasil penelitian yang telah dilakukan pada mahasiswa program studi kedokteran tingkat akhir Fakultas Kedokteran Universitas Andalas angkatan 2015, didapatkan bahwa tingkat kecenderungan gejala somatisasi responden sebagian besar berada pada kategori gejala somatisasi sedang, yaitu sebesar $26 \%$. Persentase responden yang mengalami kecenderungan somatisasi ringan sebesar $24 \%$ dan kecenderungan somatisasi berat $23 \%$. Peneliti menyimpulkan bahwa sebagian besar tingkat kecenderungan gejala somatisasi pada mahasiswa program studi kedokteran tingkat akhir Fakultas Kedokteran Universitas Andalas angkatan 2015 berada pada kisaran kategori ringan - berat.

Hasil penelitian ini sejalan dengan penelitian yang dilakukan oleh Zunhammer et al (2013), didapatkan bahwa tingkat kecenderungan gejala somatisasi responden sebagian besar berada pada kategori gejala somatisasi sedang, yaitu sebesar $64,9 \% .^{25}$

Berdasarkan hasil penelitian yang telah dilakukan, didapatkan bahwa gejala somatik yang cukup sering dialami oleh responden adalah merasa lelah atau kurang energi. Hal ini sejalan dengan penelitian yang dilakukan oleh Pratiwi et al (2018), didapatkan bahwa responden sering mengalami kelelahan, dengan nilai persentase responden yang mengalami kelelahan sebesar $81,9 \%{ }^{26}$

Stres dapat mempengaruhi munculnya sakit kepala. Stres dapat merangsang pelepasan epinefrin yang akan menstimulus nosiseptor, sehingga tubuh memberikan respon nyeri. ${ }^{27}$

Stres dapat mempengaruhi terjadinya gejala gastrointestinal. Gejala ini dapat muncul melalui 
aktivasi interaksi HPA axis dengan Brain-Gut-Axis $(B G A)$. Brain-Gut-Axis merupakan jaras interaksi antara faktor psikis dengan saluran cerna. Jalur yang dipengaruhi adalah jalur neurogen dan hormonal yang berujung pada peningkatan hormon kortisol yang dikenal sebagai hormon stres. ${ }^{28}$

Hormon kortisol yang dilepas akibat paparan stresor psikologis ini akan merangsang produksi asam lambung (faktor agresif) dan bisa menghambat prostaglandin (faktor defensif) yang bersifat proktetif pada lambung. Berkurangnya prostaglandin untuk selanjutnya akan memudahkan terjadinya kerusakan pada mukosa lambung dan bermanifestasi klinis seperti rasa kembung, mual dan rasa tidak nyaman di perut bagian atas. ${ }^{28}$

Stres juga dapat mempengaruhi siklus menstruasi. Stres merangsang Hipotalamik-pituitariadrenal axis (HPA Axis), sehingga dihasilkan hormon kortisol menyebabkan terjadinya ketidakseimbangan hormonal termasuk hormon reproduksi dan terjadi suatu keadaan siklus menstruasi yang tidak teratur. Pada saat pelepasan $\mathrm{CRH}$, secara langsung dan tidak langsung menyebabkan penurunan $\mathrm{GnRH}$ dan melalui jalur ini stres dapat menyebabkan gangguan siklus mentruasi. $^{29}$

Berdasarkan hasil analisis bivariat yang diambil dari nilai fisher's exact, didapatkan bahwa nilai $\mathrm{p}=$ 0,000 , dimana $p<0,005$. Berdasarkan hasil analisis bivariat tersebut dapat disimpulkan bahwa terdapat hubungan yang signifikan antara stres akademik dengan kecenderungan gejala somatisasi pada mahasiswa program studi kedokteran tingkat akhir Fakultas Kedokteran Universitas Andalas angkatan 2015.

Berdasarkan hasil bivariat di atas, peneliti dapat menyimpulkan bahwa stres akademik sangat mempengaruhi terjadinya gejala somatisasi. Gejala somatisasi yang berkepanjangan dapat menyebabkan hambatan di bidang sosial dan okupasi serta adanya perilaku mencari pertolongan medis yang berlebihan. Selain itu, gejala somatisasi yang berkepanjangan juga dapat menimbulkan rasa cemas dan depresi sering muncul. ${ }^{15}$

Hasil penelitian ini sejalan dengan penelitian yang dilakukan oleh Rahajeng (2016), didapatkan bahwa hasil korelasi menunjukkan bahwa terdapat hubungan yang signifikan antara stres akademik dengan kecenderungan somatisasi ( $r=0,469$ dengan $p=0,000, p<0,01)$. Simpulan yang didapatkan dari penelitian Rahajeng adalah semakin tinggi tingkat stres akademik yang dialami oleh mahasiswa tingkat akhir, maka semakin tinggi pula kecenderungan somatisasi yang dirasakan. ${ }^{30}$

Hasil penelitian ini juga sejalan dengan yang dilakukan oleh Syarif (2013), didapatkan bahwa besarnya koefisien korelasi antara kedua variabel adalah $r=0,884$ dan probabilitas $(p)=0,000(p<0,01)$, maka terdapat korelasi positif yang sangat signifikan antara variabel stres dengan variable kecenderungan somatisasi. Simpulan yang didapatkan dari penelitian Syarif adalah semakin tinggi stres, maka semakin tinggi somatisasi, dan semakin rendah stres maka semakin rendah somatisasi. ${ }^{16}$

\section{SIMPULAN}

Terdapat hubungan antara stres akademik dengan kecenderungan gejala somatisasi pada mahasiswa program studi kedokteran tingkat akhir Fakultas Kedokteran Universitas Andalas angkatan 2015.

\section{UCAPAN TERIMA KASIH}

Terima kasih kepada semua pihak yang telah membantu terlaksananya penelitian ini.

\section{DAFTAR PUSTAKA}

1. Ciccarelli SK, White J.N. Psychology. Edisi-5. London: Pearson Education; 2017.hlm. 462.

2. Jena SK. Examination stress and its effect on EEG. Int J Med Sci Public Health. 2015; 4(11): 1493-7.

3. Sutjianto M, Kandou G.D., Tucunan A.A.T. Internal and external factors correlated with stress levels medical students University of Sam Ratulangi. JIKMU.2015; 5(1): 30-42.

4. Ramli $\mathrm{NHH}$, Alavi M, Mehrinezhad SA, Ahmadi A. Academic stress and self-regulation among university students in Malaysia: Mediator role of mindfulness. Behav Sci. 2018;8(12):1-9.

5. Suwartika I, Nurdin A, Ruhmadi E. Analisis faktor yang berhubungan dengan tingkat stres akademik mahasiswa reguler program studi D III 
Keperawatan Cirebon Poltekkes Kemenkes Tasikmalaya. The Soedirman Journal of Nursing. 2014; 9(3):173-88.

6. Dermawan R, Sunnati, Rezeki S. Correlation between academic stress with gingivitis in dental undergraduate students at Syiah Kuala University. Cakradonya Dent J. 2016; 8(2):117-22.

7. Kumari A, Jain J. Examination stress and anxiety: A study of college students. GJMS. 2014; 4 (1): 31 40 .

8. Augesti G, Lisiswanti R, Saputra O, Nisa K Differences in stress level between first year and last year medical students in medical faculty of Lampung University. J Majority. 2015; 4(4): 50-6.

9. Legiran, Azis M.Z, Bellinawati N. Faktor risiko stres dan perbedaannya pada mahasiswa berbagai angkatan di fakultas kedokteran Universitas Muhammadiyah Palembang. Jurnal Kedokteran dan Kesehatan. 2015; 2(2):197-202.

10. Pathmanathan VV, Husada MS. Overview of stress level among the students in medical faculty of North Sumatera University odd semester academic year 2012/2013. E-Journal FK USU. 2013;1(1):1-4.

11. Sushil K, Mandira M, Binod R, Arun D, Rani G. An evaluation of stress in medical and dental students at Kathmandu medical college, Nepal. International Annals of Medicine. 2017;1(7):1-4

12. Busaidi ZQA. The consept of somatisation. SQU Med J. 2010;10(2):180-6.

13. Sadock BJ, Sadock VA. Kaplan \& Sadock Buku Ajar Psikiatri Klinis. Profitasari dan Tiara Mahatmi Nisa, penterjemah. Edisi ke-2. Jakarta: EGC; 2010. HIm.268-70.

14. Hadjam M.NR. Peranan Kepribadian dan Stres Kehidupan terhadap Gangguan Somatisasi. Jurnal Psikologi. 2003; (1): 36-56

15. Elvira SD, Hadisukanto G. Buku Ajar Psikiatri. Ed 2. Jakarta: Badan Penerbit FKUI; 2013. P. 287290.

16. Syarif DFT. Hubungan antara stres dengan kecenderungan somatisasi pada mahasiswi semester akhir prodi Farmasi Fakultas IImu Kesehatan Universitas Muhammadiyah Palangkaraya. Pedagorik Jurnal Pendidikan. 2013; $8(2): 72-86$.
17. Yusoff MSB, Rahim AFA. The medical student stressor questionnaire (MSSQ) manual. Kota Bahru: KKMED Publications; 2010.hlm.9-20.

18. Glerk B, Kohlmann S, Kroenke K, Spangenberg L, Zenger M, Brahler E, et al. The somatic symptom scale-8 (SSS-8) a brief measure of somatic symptom burden. JAMA internal medicine. 2014; 174(3): 399-407.

19. Chandratika D, Purnawati S. Gangguan cemas pada mahasiswa semester I dan VII program studi pendidikan dokter Fakultas Kedokteran Udayana. E-Jurnal Medika Udayana. 2014; 3(4):1-11.

20. Irkhami FL. Faktor yang berhubungan dengan stres kerja pada penyelam di PT. X. The Indonesian Journal of Occupational Safety and Health. 2015;4(1): 54-63.

21. Sharma B, Wavare R, Deshpande A, Nigam R, Chandorkar R. A study of academic stress and its effect on vital parameters in final year medical students at SAIMS medical college, Indore, Madhya Pradesh. Biomedical Research. 2011; 22 (3): $361-5$

22. Nurhayati E. Psikologi perempuan dalam berbagai perspektif. Edisi ke-1. Yogyakarta: Pustaka Belajar; 2012.

23. Umesh SS, Rahul KR, Sandeep NP. Level of stress in final year MBBS students at rural medical college: A cross-sectional study. International Journal of Medical Research \& Health Sciences. 2014;3(4):886-91.

24. Othman CN, Farooqui M, Yusoff MSB, Adawiyah R. Nature of stress among health science students in a Malaysian University. Procedia-Social and Behavioral Sciences. 2013; 249-57.

25. Zunhammer M, Eberle H, Eichhammer P, Busch V. Somatic symptoms evoked by exam stress in university students: The role of alexithymia, neuroticism, anxiety and depression. PLoS One. 2013;8(12):1-11.

26. Pratiwi R, Akbar FH, Muhiddin NH. Relationship between stress level, fatigue symptoms, and sleep quality with oral health behavior among preclinical student faculty of pharmacy, Indonesia. Pesq Bras Odontoped Clin Integr. 2018;18(1): e4070. 
27. Cathcart S, Winefield AH, Lushington K, Rolan P. Stress and tension-type headache mechanisms. cephalgia. 2010;30(10):1250-67.

28. Murni AW. Hubungan stres psikologis dengan kortisol plasma, ekspresi inter leukin-6 dan inter leukin-8 serta aktivitas Helicobacter pylori pada dispepsia fungsional [disertasi]. Padang: Fakultas Kedokteran, Universitas Andalas; 2017.

29. Tombokan KC, Pangemanan DHC, Engka JNA.
Hubungan antara stres dan pola siklus menstruasi pada mahasiswa kepaniteraan klinik madya ( coassistant) di RSUP Prof.Dr.R.D. Kandou Manado. Jurnal e-Biomedik. 2017; 5(1):1-7.

30. Rahajeng I. Hubungan antara stres akademik dengan kecenderungan somatisasi pada mahasiswa tingkat akhir [skripsi]. Yogyakarta: Fakultas Psikologi, Universitas Gadjah Mada; 2016 